\title{
SPECIAL FEATURE
}

\section{A mother's tale: escalator amputates four fingers}

\author{
Claire Adamson
}

Her hand would not come out. It was sucked in more and more. It happened on the 8 th of September 1989. I had never heard of anyone being injured in the space at the side of an escalator step before. As I later discovered, however, these gaps had been injuring nearly one person a month in Montreal alone.

Thea is our second daughter so we had experience caring for toddlers. Our children were watched continuously in our "babyproofed" house. We live downtown and have never owned a car. Instead we travel by Metro, bus, or on foot. When, at 18 months, Thea became too heavy for a "snuggly" we began to use a stroller on outings.

On this occasion, being age 2 , she did not want to go in the stroller as we approached the escalator. She could walk well and her independent nature made her decide to travel on foot. Thea was carrying a bag of raisins but dropped the bag on the escalator step. When she went to pick it up, her hand went into the space between the step and the balustrade (side) of the escalator. This space was 5/16 of an inch or more (although the code specifies that it must not exceed 3/16). The razor sharp edge cut into the skin of her hand, catching it. Although the skirt panel is supposed to be treated with a friction reducing material, her hand was locked in. It was pulled in farther as the escalator moved. Someone shouted, "Stop the escalator!" but only after her hand had

1812 Baile, Montreal, PQ H3H 1P4, Canada

Correspondence to: Mrs Adamson (e-mail: adamsonclaire@hotmail.com). passed through the step did it stop. I held her hand together with one hand and picked her up with the other arm.

Her hand was so badly crushed it could not be reattached. I wished the injury had happened to me instead. She had her whole life to live.

Because the side of the step space exceeded the standard described by the Canadian Standards Association, we decided to press charges. We felt that unless someone acted, this dangerous condition could injure another child. Our expert witness was an escalator consultant, who wrote specifications for escalator and elevator installations. After interrogating the Transit Commission's engineers, we discovered that there had been problems with these escalators since their installation in 1967. Our lawyer asked questions about every document the Transit Commission supplied. This included a file box full of incident reports for the preceding 10 years. We had to pay $\$ 1000$ per month to the lawyer to pursue our case as well as $\$ 10000$ as a retainer. The trial finally took place seven years after the injury.

The judge had read our disposition carefully, and asked good questions. I was present for all 11 days of the trial. We showed a video about the plates fixed to the side of escalator steps, and the other side showed one about escalator safety-not yet shown in schools. We were allowed to have witnesses who were also injured on Metro escalators. Thea appeared on the second last day. She answered questions clearly, and did not hesitate when asked to approach the judge to show her hand and a prosthetic glove. In the settlement, Thea received interest for the time before the trial, almost doubling her compensation to a total of over $\$ 600000$.

Equally important, many escalators are now improved, though they are still not as safe as they could be. Before Thea's injury only 29 of the 120 Montreal Metro escalators met code standards. Most were an unsafe model from England in which steps are attached in such a way that they are able to float from side to side. This movement pushes the balustrades apart and adjustment has to be made frequently. The Metro knew about this problem and six years before Thea's injury had started to clamp the steps in position. Newer stations use safer models, now popular in London and Paris.

If Thea had been buckled into a stroller, she would probably still have her hand today. But 
apart from her preference to walk, the Canadian Standards Association disapproves of stroller use on escalators, arguing that their wheels could become caught in the combplate. This was realistic when combplates had 1 inch wood teeth, but I cannot imagine how a modern day wheel could get caught in a modern day escalator. Another reason given for this regulation is that a parent might allow the stroller to fall down the escalator. But when the pride of your life is in your hands, it is unlikely that you would allow it to escape from your grip.
Sadly, I am now more aware of other dangers in our everyday lives. Every injury can be and should be prevented. I have requested that the maximum space at the side of the steps be further reduced and have asked that stroller use on escalators be reviewed. I have asked that all transit passengers be warned about escalator risks. Information pamphlets should be distributed to daycare centres, schools, and hospitals. Toddlers, teens, and seniors still remain high risk passengers for escalators. No one else should have to lose a hand before they are made safer.

\section{One adolescent's injury—a continuing saga}

Roger Tonkin

Sometimes we don't respond to the statistics on trauma among adolescents because they are so mind numbing. Stereotypical views of adolescents as reckless and irresponsible also may inhibit our prevention efforts. Too often we focus on mortality and ignore morbidity. The difference between the two is measured in fractions of a second at the time of the injury event and forever in the lifetime of the survivors. Let me illustrate what I mean by telling you about Rhonda.

I first saw Rhonda as a patient when she was 15 years old. She had come from the Okanagan Valley and was referred because of acting out behaviour. She came from a religious family. Her mother was a homemaker and father ran a small contracting business. The family was very respected, had a reasonable standard of education, and a comfortable lifestyle. Rhonda had been an above average student who did not smoke or drink, and was an accomplished pianist. At least that is the way things were before she was injured.

It was a hot, clear summer day when Rhonda hitched a ride home from a schoolmate. They had been at the beach with friends. Steve was 16 years old, had had his driver's license for three months, and was driving his "new" pick-up truck. He was very proud of it. They set out for town with four teens in the front cab and three, including Rhonda, sitting in the back. They had shared a few beers so every one was happy but not drunk. No one except Steve was wearing a safety belt. It was supposed to be a fun filled 20 minute ride but it proved to have a lifetime impact.

The last thing Rhonda remembered was the three of them sitting in the back singing to the booming rock music. The crash reconstruction showed that Steve lost control on a curved stretch of gravel road. The truck rolled before coming to a stop, upside down, in the ditch. The teens in the back were all thrown clear but one boy hit a tree and died while the truck crushed the other boy.
Rhonda was more fortunate. She was found, unconscious, but otherwise uninjured some 10 feet away. She was transported 150 miles to the nearest neurosurgical unit. The next thing she remembered was waking up in hospital with her neck in traction and a splint on her right arm. The next few days were pretty much a blur. She was gradually ambulated, and discharged a week later and soon returned to school. Life was returning to normal, and everyone was telling her how lucky she was.

She later told me that, even then, she didn't feel lucky. She felt guilty for being alive, sad about losing two of her friends, and mad at Steve for getting off scot-free. Meanwhile, the crash left her with a disfigured hand, no longer able to play the piano, and with parents who seemed to always be hovering over her. Besides, she still had the coroner's inquest to look forward to.

The next two months were a disaster. On October 1, her birthday, she decided to celebrate with her friends. She got roaring drunk and became so depressed that she ended up in hospital on suicide watch. It was later reported that she had begun acting inappropriately at school, laughing at nothing or talking loudly, starting fights, and coming to school drunk. The family called the school counsellor to see how she was doing and discovered that she was missing classes and getting failing grades. Before they knew it, she was suspended.

At home, she just sat around the house all day and partied most nights. Sometimes she wouldn't come home at all and was beginning to hang out with an older crowd. Her parents worried that she was doing drugs and would become pregnant. These concerns prompted the appointment with me.

I did a full interview and physical assessment and saw her parents as well. I found Rhonda to be a pleasant, attractive, modest young woman who was perplexed by the way her family had arranged for her to see me. She acknowledged
Correspondence to: Dr Tonkin.
Box 19, Site 3, Gabriola Island, BC, V0R 1X0, Canada 
that her lifestyle had changed but denied it was influenced by the crash or her injuries. She was the same old Rhonda, just having more fun. Why should they make such a big deal?

Rhonda's behaviour didn't strike me as particularly rebellious but I acknowledged that her drinking was out of character for her and for her family. Based on the personality changes, history of binge drinking in the weeks before the accident, her subsequent rages, failing school performance, blackouts, and bouts of depression, I thought she was an early alcoholic. Rhonda was certainly not convinced but I went ahead and recommended alcohol and drug counselling and a negotiated return to school. Things seemed headed in the right direction.

In fact, her school performance didn't improve, she began to go to all weekend drinking parties, and would return home in a terrible state. After much agonizing, her parents, fearing the impact of her behaviour on the other children, kicked her out of the house. They arranged for her to live with an uncle, and I agreed to see her weekly.

But coming to Vancouver was not the end of Rhonda's rocky road. In fact, it seemed to only increase her risk taking behaviour. She continued drinking, was sexually assaulted by an older man, moved in with a physically abusive boyfriend, and lost touch with her family. But she kept coming to see me and bit by bit the pieces of the puzzle began to come together.

While in Vancouver she became even more socially inappropriate. She was back at school but couldn't remember where her locker was at school, was found to be performing at a grade 8 level in math (she had been in an advanced math class in grade 10), and was becoming very impulsive. This was when I began to wonder about my diagnosis. Was the head injury a more significant factor than her supposed alcoholism?

We arranged for her to be assessed by a group who specialized in reviewing head injury cases for the Insurance Corporation of BC (ICBC). Their report was quite clear, confirming the importance of the head injury. The psychological test results resulted in recommending a different rehabilitation program. She started on one intended to retrain her in some basic cognitive functions. She was slow to accept this new diagnosis and the change of direction it would require but liked the

\section{My sister's death}

\footnotetext{
Department of

Epidemiology and

Biostatistics, McGill

University, 1020 Pine

Ave W, Montreal H3A

1A2, Canada

Correspondence to: $\mathrm{Ms}$ Olivier (e-mail: marielle@ epid.lan.mcgill.ca).
}

\section{Marielle Olivier}

Editors note: Just before Christmas the sister of one of my colleagues was killed by a drunk driver. I asked for the details and what follows is her reply. I realize this is not an issue that directly applies to children and adolescents, therapist and realized that attending an ICBC prescribed rehabilitation program might increase her chances of obtaining financial compensation from the crash. I confessed to her parents that I was afraid that she would blow the money on booze and drugs.

Eventually Rhonda graduated from high school and got a job as a waitress. Her lifestyle improved a little. She would laugh and tell me "I am mellowing". When she turned 19 the compensation money came and she blew it all on clothes and partying. Six months later she was broke and desperate. It was then that she met Pete. Within a year they were married, she was pregnant, and both were back living in her home town.

Rhonda called me recently. I hadn't heard from her in two years. It was her 21 st birthday. She told me she just decided to phone me to say "hello" and let me know that she was happy in her marriage, was expecting her second child, had stopped drinking, had reconnected with her family, and was taking some community college courses. I told her about an article I read on subtle head injuries and we joked about how I had accused her of being an alcoholic. She remembered that I had predicted she was going to end up on skid row. How wrong I was! However, in those days we paid little attention to "minor head injuries". Today, I hope we would know better and would not let a year go by without moving more quickly to provide appropriate cognitive therapy.

Any injury prevention specialist could review the crash and Rhonda's subsequent history and identify many opportunities for prevention. For example, zero tolerance of drinking-driving, graduated licencing, better police supervision, safety belt enforcement, emergency first aid training, more accessible ambulance services, and better brain injury assessment programs. The reality is that we still sometimes overlook these opportunities.

Rhonda's tragedy was not a statistical abstraction and the clinical challenges she presented ended up consuming an incredible amount of resources. She has, with characteristic adolescent resiliency, responded to the challenges. Rhonda seized the opportunity to build a new life for herself. She is fortunate the story ended as well as it did but the long term impact on herself and her family remains to be assessed. but in this instance the other victims were the adolescent children. In any case, adolescents who drive drunk are very much our concern, and the manner in which any intoxicated offender is dealt with in most countries is out- 
rageous. In a later issue we will publish an account of how this problem is handled in various countries.

By way of preview, it is usually appalling. The most promising, albeit partial solution, may rest with insurance companies who adjust premiums for those who install interlock devices. But what about prosecuting those who serve the driver? How effective are more severe penalties? I welcome comments from readers.

It is indeed a difficult experience to go through. My young sister was so full of energy. She was teaching physical education and enjoying life very much. Besides doing many sports, she was also taking painting and drawing lessons, on top of taking care of her family. Her husband is a physician and was very busy at the clinic and the hospital. So she was always there to take the kids to their soccer and hockey games, etc. She leaves behind three teenaged boys and a husband that she still loved after some 20 years of marriage. And they all needed her so much...

What happened is the following: on a Saturday afternoon (December 12th), she was driving back home after having done some Christmas shopping. It was around 17:00 so it was dark but the weather and road conditions were fine. She was on a secondary road with no street lights. She was alone in the car. On the other side came that drunk driver. He moved on her side and hit her directly (in French, "collision frontale"). She seems to have died right away, probably because she had her neck broken. She had no cushion (airbag or coussin gonflable) in her car.

Of course the other driver only had minor injuries. It is always like that... It seemed that he had drunk about 10 beers before driving his car, according to the test that was done on him. And clearly no one stopped him from driving his car after he left his office's Christmas party.

It is terribly unfair. It simply makes no sense that someone can take someone else's life away forever just like that, in a couple of seconds. It is so unfair to those children who have lost their mother much too soon. Life is incredibly fragile!!! I wonder what we can do so that things like that don't happen anymore. Certainly by stopping people that we know are drunk from driving. People were saying that the driver was a good guy who usually didn't drink too much. How many such good guys are there on the road, threatening innocent people's lives? Having more severe laws doesn't seem to be efficient, at least not for everyone. If that guy goes to prison, will it convince other good guys to be serious about not drinking and driving? Maybe.... 